\title{
Rancang Bangun Sistem Informasi Penjualan Komputer Berbasis Website
}

\author{
Partono \\ Fakultas Komputer, Universitas Ma'some, jl. Raya Cipacing No. 22 Jatinangor 45363 Jawa Barat, \\ Telp: (022) 7798340 \\ e-mail: partono@masoemuniversity.ac.id \\ Submitted Date: September $07^{\text {th }}, 2020$ \\ Revised Date: October $22^{\text {nd }}, 2020$ \\ Reviewed Date: October $09^{\text {th }}, 2020$ \\ Accepted Date: November 02 ${ }^{\text {nd }}, 2020$

\begin{abstract}
There are several problems that arise in CV. X, in terms of service and sales methods, include sales transactions made only in places available in the company, limited service time because it is only done during working hours, and a lack of means of communication because orders made by telephone are constrained in providing a physical picture product. Therefore, the design of a website-based computer sales information system can make it easier to provide information to the wider community and also make it easier to make transactions at any time. The writing method used is descriptive method. While the development tool for designing this system uses a design tool in the form of Unified Modeling Language (UML). The diagrams used include: Use Case Diagrams, Sequence Diagrams and Class Diagrams and the development of this system uses PHP programming. Implementation of website-based computer sales system at CV. This $\mathrm{X}$ can make it easier for prospective buyers to access information about the company and about the products offered online, making it easier for prospective buyers to get the information needed to make it easier to make transactions online without depending on the company's location, can serve sales transactions without depending on company working hours.
\end{abstract}

Keywords: Sales; Computers; Design; Systems; Information; UML; Website

\section{Abstrak}

Ada beberapa masalah yang muncul pada CV. X dalam hal metode pelayanan dan penjualan meliputi transaksi penjualan yang dilakukan hanya di tempat yang tersedia di perusahaan, waktu pelayanan terbatas karena hanya dilakukan pada jam kerja, dan kurangnya sarana komunikasi karena pemesanan yang dilakukan melalui telepon terkendala dalam penyediaan produk gambar fisik. Oleh karena itu perancangan sistem informasi penjualan komputer berbasis website dapat semakin memudahkan dalam memberikan informasi kepada masyarakat luas dan juga memudahkan dalam melakukan transaksi setiap saat. Metode penulisan yang digunakan adalah metode deskriptif. Sedangkan alat pengembangan untuk perancangan sistem ini menggunakan alat perancangan berupa Unified Modeling Language (UML). Diagram yang digunakan termasuk Use Case Diagram, Sequence Diagram dan Class Diagram. Pengembangan sistem ini menggunakan pemrograman PHP. Implementasi sistem penjualan komputer berbasis website di CV. X ini dapat memudahkan calon pembeli untuk mengakses informasi tentang perusahaan dan tentang produk yang ditawarkan secara online, sehingga memudahkan calon pembeli mendapatkan informasi yang dibutuhkan untuk memudahkan melakukan transaksi secara online tanpa tergantung lokasi perusahaan, dapat melayani transaksi penjualan tanpa tergantung jam kerja perusahaan.

Kata Kunci: Penjualan; Komputer; Desain; Sistem; Informasi; UML; Website

\section{Pendahuluan}

Dalam era globalisasi seperti sekarang internet memegang peranan hampir dalam segala aspek kehidupan. Internet mempermudah kita melakukan berbagai aktivitas seperti berinteraksi, berkomunikasi, bahkan melakukan perdagangan dengan orang lain dari segala penjuru dunia dengan murah, cepat dan mudah. Dengan perkembangan internet ini, berkembang pula berbagai peluang usaha di mana transaksinya dapat dilakukan secara online. 
Penggunaan aplikasi berbasis website/internet sebagai media perdagangan terus meningkat dari tahun ke tahun. Hal ini disebabkan oleh berbagai manfaat yang didapat oleh perusahaan ataupun konsumen. Kegiatan transaksi secara online dapat menekan biaya barang dan jasa, serta dapat meningkatkan kepuasan konsumen sepanjang menyangkut kecepatan untuk mendapatkan barang yang dibutuhkan dengan kualitas yang terbaik sesuai dengan harganya. Untuk mewujudkan hal ini perlu adanya pemanfaatan sistem komputerisasi yang berbasis web disebut juga konsep online shopping. Dengan website kita dapat menghadapi tantangan di era globalisasi seperti sekarang khususnya dalam hal perdagangan.

Konsep online shopping dengan memanfaatkan website menyediakan banyak memberikan kemudahan dan kelebihan apabila dibandingkan dengan konsep belanja yang konvensional. Disamping proses transaksi dapat lebih cepat, juga internet menyediakan hampir semua barang atau jasa yang kita perlukan. Sampai dengan saat ini media internet menyebabkan banyak individu maupun organisasi yang sudah mulai mencoba menawarkan berbagai macam produknya dengan memanfaatkan sistem penjualan berbasis website.

Hasil penelitian di CV. X yang melakukan penjualan secara konvensional ditarik kesimpulan bahwa belum optimalnya penjualan, dapat kurangnya promosi yang dilakukan. Jangkauan penjualan terbatas pada satu daerah dan belum menjangkau ke berbagai daerah. CV. X belum mempunyai sarana untuk memasarkan produk dengan jangkauan yang luas.

Kebutuhan akan teknologi dan informasi sangat tinggi untuk membantu berbagai jenis bidang pekerjaan manusia (Taufiq, Magfiroh, Yusuf, \& Yulianti, 2020). Teknologi informasi ditujukan untuk membantu pekerjaan dengan menyediakan informasi dan melakukan berbagai tugas yang berhubungan dengan pengolahan informasi (Hanum \& Saifudin, 2019). Dalam proses penjualan tersebut dibutuhkan sebuah informasi untuk melakukan transaksi penjualan. Informasi penjualan ini menjadi salah satu hal yang sangat dalam aktifitas di CV. X. Waktu pelayanan penjualan kegiatannya adalah sebagai berikut: a. Waktu Pelayanan, jam kerja dari hari Senin sampai dengan hari Sabtu, pukul 08.00 - 17.00 WIB. Tempat Pelayanan, tempat pelayanan dilakukan di CV. X; Media Promosi Melalui leaflet atau selebaran ukuran A4 yang berisi gambar produk dan daftar harga yang disebar sekitar lingkungan perusahaan. Dari "mulut ke mulut" berupa penyampaian pesan atau obrolan sesama teman atau keluarga mengenai produk dan harga produk yang dikeluarkan CV. X. b. Sarana Komunikasi, sarana komunikasi yang digunakan untuk pemesanan barang dapat secara langsung ataupun dengan melalui telepon.

Hasil pengamatan langkah-langkah yang dilakukan CV. X mempunyai berbagai kelemahan atau keterbatasan, yaitu: Tempat atau lokasi, hanya dilakukan di tempat perusahaan maka jangkauan pasarnya terbatas, Waktu pelayanan hanya dilakukan pada jam kerja sehingga di luar jam kerja tidak dapat melayani pemesanan, Jangkauan media promosi yang sekarang tidak dapat mencapai pasar yang lebih luas, dan dalam sarana informasi produk perusahaan belum menyediakan informasi produk dalam bentuk apapun, sehingga apabila konsumen ingin mengetahui informasi mengenai alat-alat komputer harus langsung datang ke perusahaan.

Oleh karena itu diperlukan sebuah sarana atau fasilitas yang dapat melakukan transaksi maupun mengakses suatu informasi tanpa dibatasi pada sumber informasi, tempat/lokasi, jam kerja, dan jangkauan media promosi dalam menjangkau pasar yang lebih luas. Dari masalah tersebut termotivasi untuk membuat suatu rancangan berupa sistem penjualan berbasis website menggunakan media internet melalui penerapan online shopping hal ini dilakukan guna meminimalkan waktu proses transaksi dan dapat meningkatkan jumlah konsumen sehingga tercapainya tujuan finansial perusahaan.

Berdasarakan latar belakang yang telah diuraikan maka cakupan dalam penelitian ini mencakup penjualan online komputer di CV. X, adapun batasan masalahnya adalah: Menyediakan sarana informasi berupa Produk, Sistem informasi penjualan online, dan Menyediakan sarana komunikasi melalui komentar (Buku Tamu).

Sedangkan maksud dan tujuan, adalah menyelesaikan permasalahan yang dialami oleh perusahaan tersebut seperti uraian dalam Latar belakang. Dengan demikian tujuan dari perancangan website ini adalah: untuk meningkatkan waktu pelayanan yang terkait dengan cara online tanpa batas, sebagai media promosi yang dapat menjangkau pasar lebih luas, dan sebagai sarana komunikasi alternatif. 


\section{Landasan Teori}

\subsection{Konsep Dasar Sistem Informasi}

Sistem informasi adalah kumpulan dari sub-sub sistem yang saling terintegrasi dan berkolaborasi untuk menyelesaikan masalah tertentu dengan cara mengolah data sehingga memiliki nilai tambah dan bermanfaat bagi pengguna (Taufiq, 2018). Suatu sistem informasi adalah sekumpulan komponen yang saling terkait yang mengumpulkan, memanipulasi, dan menyebarluaskan data dan informasi untuk memfasilitasi perencanaan, kontrol, koordinasi, analisis dan pengambilan keputusan di perusahaan dan organisasi lain. Ini set terdiri dari orang, perangkat keras, perangkat lunak, jaringan komunikasi dan sumber data (Alter, 2008).

Dari pengertian sistem informasi di atas dapat disimpulkan bahwa sistem informasi adalah kombinasi manusia, fasilitas alat teknologi, media, prosedur atau pengendalian yang bermaksud menata jaringan komputer yang menjadi dasar pengambilan keputusan secara tepat serta menghasilkan informasi.

Sistem informasi dapat terdiri dari sub sistem-sub sistem yang disebut dengan istilah blok sistem, yaitu blok masukan, blok model, blok keluaran, blok teknologi, blok basis data dan blok kendali (Wilkinson, 1992). Sebagai suatu sistem, keenam blok tersebut masingmasing saling berinteraksi satu dengan yang lainnya membentuk satu kesatuan untuk mencapai sasarannya.

Adapun perangkat pengembangan sistem bagi pemrograman berorientasi objek ini adalah Unified Modeling Language (UML). UML (Unified Modeling Language) adalah sebuah bahasa untuk menetukan, visualisasi, kontruksi, dan mendokumentasikan artifact (bagian dari informasi yang digunakan atau dihasilkan dalam suatu proses pembuatan perangkat lunak (Muslihudin \& Oktavianto, 2016). Artifact dapat berupa model, deskripsi atau perangkat lunak) dari system perangkat lunak, seperti pada pemodelan bisnis dan sistem nonperangkat lunak lainnya.

Uraian mengenai alat bantu UML meliputi (a). Diagram Use Case menggambarkan unit fungsionalitas yang disediakan oleh sistem. Tujuan utama diagram use-case adalah untuk membantu tim pengembangan memvisualisasikan persyaratan fungsional suatu sistem, termasuk hubungan "aktor" (manusia yang akan berinteraksi dengan sistem) ke proses penting, serta hubungan di antara penggunaan yang berbeda kasus. Diagram use-case umumnya menunjukkan kelompok use case, baik semuanya Use Case untuk sistem lengkap, atau breakout dari grup tertentu Use Case dengan fungsionalitas terkait (misalnya, semua Use Case terkait administrasi keamanan) (Bell, 2003). (b). Class Diagram, diagram kelas menunjukkan bagaimana entitas yang berbeda (orang, benda, dan data) berhubungan satu sama lain; dengan kata lain, ini menunjukkan struktur statis sistem. Diagram kelas dapat digunakan untuk menampilkan kelas logis, yang Biasanya adalah hal-hal yang dibicarakan oleh para pebisnis dalam organisasi tentang band rock, $\mathrm{CD}$, sandiwara radio; atau pinjaman, hipotek rumah, mobil pinjaman, dan suku bunga. Diagram kelas juga dapat digunakan untuk menunjukkan kelas implementasi, yang biasanya dilakukan oleh programmer (Bell, 2003). (c). Sequence Diagram, diagram urutan menunjukkan aliran mendetail untuk kasus penggunaan tertentu atau bahkan hanya bagian dari kasus penggunaan tertentu. Mereka hampir cukup jelas; mereka menunjukkan panggilan antara objek yang berbeda dalam urutan dan kalengnya menunjukkan, pada tingkat yang mendetail, panggilan yang berbeda ke objek yang berbeda. Diagram urutan memiliki dua dimensi: Dimensi vertikal menunjukkan urutan pesan/panggilan dalam urutan waktu terjadinya; Dimensi horizontal menunjukkan contoh objek yang dipesan terkirim (Bell, 2003). (d). Diagram statechart memodelkan status berbeda di mana kelas dapat berada dan bagaimana kelas itu bertransisi dari satu negara bagian ke negara bagian lain. Dapat dikatakan demikian setiap kelas memiliki status, tetapi setiap kelas tidak boleh memiliki statechart diagram. Hanya kelas dengan status "menarik" - yaitu, kelas dengan tiga atau lebih status potensial selama aktivitas sistem seharusnya dimodelkan (Bell, 2003). (e). Activity Diagram, diagram aktivitas menunjukkan 
aliran kontrol prosedural antara dua atau lebih banyak objek kelas saat memproses suatu aktivitas. Diagram aktivitas bisa digunakan untuk memodelkan proses bisnis tingkat yang lebih tinggi di tingkat unit bisnis, atau untuk memodelkan tindakan kelas internal tingkat rendah (Bell, 2003). (f). Diagram komponen memberikan tampilan fisik sistem. Tujuannya adalah untuk menunjukkan ketergantungan perangkat lunak pada perangkat lunak lain komponen (misalnya, pustaka perangkat lunak) dalam sistem. Diagramnya bisa ditampilkan pada tingkat yang sangat tinggi, hanya dengan komponen berbutir besar, atau bisa juga ditampilkan di level paket komponen (Bell, 2003). (g). Deployment Diagram menunjukkan bagaimana sistem akan digunakan secara fisik di lingkungan perangkat keras. Tujuannya adalah untuk menunjukkan di mana perbedaannya komponen sistem secara fisik akan berjalan dan bagaimana mereka akan melakukannya berkomunikasi satu sama lain. Karena diagram model fisik runtime, staf produksi sistem akan memanfaatkan ini secara signifikan diagram (Bell, 2003).

\subsection{Konsep Sistem Database dan File}

Database adalah kumpulan data, biasanya menggambarkan aktivitas salah satu atau organisasi yang lebih terkait (Fathansyah, 1999). Misalnya, suatu database universitas mungkin berisi informasi tentang berikut ini:

- Entitas seperti mahasiswa, fakultas, kursus, dan ruang kelas.

- Hubungan antar entitas, seperti pendaftaran siswa dalam kursus, fakultas kursus pengajaran, dan penggunaan ruangan untuk kursus.

Sistem manajemen basis data, atau DBMS, adalah perangkat lunak yang dirancang untuk membantu memelihara dan memanfaatkan koleksi besar data (Kristanto, 1994), dan kebutuhan untuk sistem semacam itu, juga karena penggunaannya, berkembang pesat. Itu alternatif untuk menggunakan DBMS adalah dengan menggunakan ad hoc pendekatan yang tidak terbawa dari satu aplikasi ke yang lain; Misalnya untuk menyimpan data dalam file dan menulis kode khusus aplikasi untuk mengelolanya (Singh, 2015).

\section{$3 \quad$ Metode Penelitian dan Metodologi \\ Pengembangan Sistem}

Metodologi yang digunakan adalah metode penulisan deskriptif. Metode ini merupakan penelitian yang berusaha mendeskripsikan dan menginterprtasikan data yang diperoleh, misalkan kondisi atau hubungan yang ada, pendapat yang berkembang, proses yang sedang berlangsung, akibat atau efek yang terjadi atau tentang kecendrungan yang tengah berlangsung.

Teknik pengumpulan data dilakukan dengan berbagai cara, yaitu observasi, dilakukan dengan cara mengamati proses penjualan yang dilakukan oleh bagian marketing, wawancara, dilakukan dengan cara menanyakan berbagai hal yang berkaitan dengan masalah yang diteliti secara tatap muka, studi pustaka, dilakukan dengan cara melakukan kajian dan pengumpulan data yang berkaitan dengan teori dokumentasi, dan pelaksanaan dokumentasi, dilakukan dengan cara meneliti dokumen-dokumen yang berhubungan dengan permasalahan yang sedang diteliti.

Pengembangan sistem yang digunakan dalam penelitian ini menggunakan metode SDLC (System Development Life Cycle) (Nugroho, 2005). Di mana alat pengembangannya berupa UML (Unified Modeling Language) yang dibantu beberapa diagram seperti Class Diagram, Activity Diagram, Use Case Diagram, dan Sequence Diagram.

\section{Analisis Sistem}

\subsection{Gambaran Sistem dan Struktur Organisasi}

Gambaran sistem ini merupakan sebuah penjelasan mengenai sebuah sistem yang sedang berjalan di CV. X. Sistem tersebut meliputi beberapa gambaran seperti struktur organisasi, deskripsi prosedur kerja, deskripsi dokumen, dan identifikasi kebutuhan pemakai.

Dalam sebuah organisasi diperlukan sebuah struktur organisasi. Struktur organisasi merupakan suatu susunan dan hubungan antara tiap bagian serta posisi yang ada pada suatu organisasi atau perusahaan dalam menjalankan kegiatan operasional untuk mencapai tujuan. Struktur Organisasi menggambarkan dengan jelas pemisahan kegiatan pekerjaan antara yang satu dengan yang lain dan bagaimana hubungan aktivitas dan fungsi dibatasi.

Struktur organisasi CV. X digambarkan dalam sebuah bagan stuktur yang sistematis sehingga setiap bagian dapat memiliki tanggung 
jawab terhadap fungsi dan tugasnya sehingga mempunyai tanggung jawab masing-masing terhadap tugasnya. Bagan struktur organisasi di CV. $\mathrm{X}$ adalah sebagai berikut:

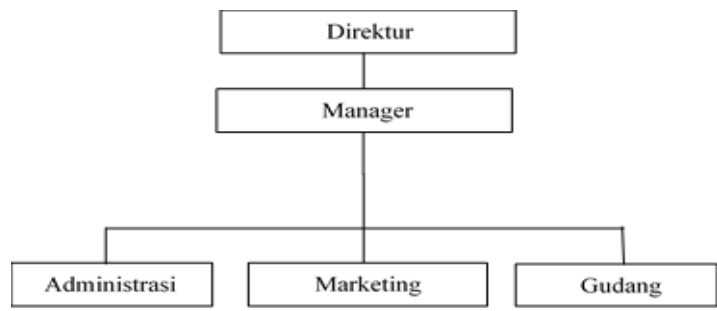

Gambar 1 Struktur Organisasi CV. X

Adapun tugas dari masing-masing pekerjaan adalah (a). Direktur, Direktur merupakan posisi tertinggi di CV. X yang merupakan pimpinan di perusahaan dan sekaligus juga sebagai pemilik perusahaan. Di mana tugasnya mengkontrol perkembangan perusahaan dan kinerja para pegawainya, (b). Manager, Tugas pokok seorang manager di CV. X yaitu memanager kegiatan operasional dan bertanggung jawab kepada owner. Adapun tugas lain dari seorang manager yaitu: Mengelola dan mengatur anggaran-anggaran untuk setiap bagian, Membuat marketing plan untuk setiap produk yang dimiliki perusahaan berkoordinasi dengan bagian marketing, Merencanakan, mengembangkan dan mengimplementasikan strategi pengembangan perusahaan, (c). Marketing, Marketing merupakan bagian yang bertugas memasarkan dan mempromosikan produk CV. X, adapun tugas lainnya adalah: Merancang, dan mengatur strategi penjualan, Melakukan penulusaran pasar secara optimal, Melakukan berbagai macam penawaran, Melakukan kegiatan transaksi, (d). Administrasi, Administrasi merupakan bagian yang mengatur keuangan perusahaan, adapun tugasnya adalah: Merencanakan dan mengelola keuangan perusahaan, Mengelola, mengadministrasikan dan membuat pertanggungjawaban atas setiap pemasukan dan pengeluaran perusahaan, dan Bertanggung jawab mengenai keuangan kepada manager perusahaan dan Membuat pembukuan, (e). Gudang, merupakan bagian yang bertanggung jawab dalam pengadaan barang, adapun tugasnya adalah: Mengkontrol stok barang yang ada, dan Melakukan pengadaan produk.

\subsection{Kebutuhan Informasi}

Dalam pembuatan Sistem informasi penjualan online berbasis web ini diperlukan informasi yang benar-benar dapat memberikan keterangan yang jelas mengenai CV. X itu sendiri, cara transaksi dan produknya. Oleh karena itu informasi yang diperlukan yaitu

Tabel 1 Tabel Kebutuhan Informasi

\begin{tabular}{|l|l|l|}
\hline No & \multicolumn{1}{|c|}{ Kebutuhan Informasi } & \multicolumn{1}{|c|}{ Tujuan } \\
\hline 1 & $\begin{array}{l}\text { Informasi mengenai Produk } \\
\text { Baru }\end{array}$ & $\begin{array}{l}\text { Pengunjung } \\
\text { dan Member }\end{array}$ \\
\hline 2 & $\begin{array}{l}\text { Informasi mengenai Buku } \\
\text { Tamu }\end{array}$ & $\begin{array}{l}\text { Pengunjung } \\
\text { dan Member }\end{array}$ \\
\hline 3 & $\begin{array}{l}\text { Informasi mengenai } \\
\text { Keranjang Belanja }\end{array}$ & Member \\
\hline 4 & $\begin{array}{l}\text { Informasi mengenai Cara } \\
\text { Pemesanan }\end{array}$ & Member \\
\hline 5 & $\begin{array}{l}\text { Informasi mengenai } \\
\text { Konfirmasi Pembayaran }\end{array}$ & Member \\
\hline 6 & $\begin{array}{l}\text { Informasi mengenai kelola } \\
\text { product profil buku tamu, } \\
\text { keranjang belanja, cara } \\
\text { pemesanan dan konfirmasi } \\
\text { pembayaran }\end{array}$ & Admin \\
\hline
\end{tabular}

\subsection{Kebutuhan Fungsional}

Untuk penjelasan mengenai deskripsi kebutuhan fungsional akan dijelaskan lebih rinci sebagai berikut:

\section{Pengunjung Website}

Tabel 2 Kebutuhan Fungsional Pengunjung

\begin{tabular}{|c|l|l|}
\hline No & Kode Kebutuhan & Deskripsi kebutuhan \\
\hline 1 & Req-PN-1 & Browse Home \\
\hline 2 & Req-PN-2 & Browse Product \\
\hline 3 & Req-PN-3 & Browse Profil \\
\hline 4 & Req-PN-4 & Browse Buku Tamu \\
\hline 5 & Req-PN-5 & Regristrasi member \\
\hline
\end{tabular}

\section{Member}

Tabel 3 Kebutuhan Fungsional Member

\begin{tabular}{|r|l|l|}
\hline No & \multicolumn{1}{|c|}{$\begin{array}{c}\text { Kode } \\
\text { Kebutuhan }\end{array}$} & \multicolumn{1}{|c|}{ Deskripsi kebutuhan } \\
\hline 1 & Req-ME-1 & Login member \\
\hline 2 & Req-ME-2 & Browse Home \\
\hline 3 & Req-ME-3 & Browse Product \\
\hline 4 & Req-ME3.1 & Browse Komputer \\
\hline 5 & Req-ME3.2 & Browse Leptop \\
\hline 6 & Req-ME-4 & Browse Member \\
\hline 7 & Req-ME-5 & Browse Profil \\
\hline 8 & Req-ME-6 & Browse Keranjang Belanja \\
\hline 9 & Req-ME-6.1 & Browse Cara Pembelian \\
\hline 10 & Req-ME-6.2 & $\begin{array}{l}\text { Browse Konfirmasi } \\
\text { Pembayaran }\end{array}$ \\
\hline 11 & Req-ME-7 & Browse Buku Tamu \\
\hline 12 & Req-ME-8 & Logout \\
\hline
\end{tabular}




\section{Admin}

Tabel 4 Kebutuhan Fungsional Admin

\begin{tabular}{|c|l|l|}
\hline No & \multicolumn{1}{|c|}{$\begin{array}{c}\text { Kode } \\
\text { Kebutuhan }\end{array}$} & \multicolumn{1}{|c|}{ Deskripsi kebutuhan } \\
\hline $\mathbf{1}$ & Req-AD-1 & Login Admin \\
\hline 2 & Req-AD-2 & Extend: Kelola Home \\
\hline 3 & Req-AD-2.1 & Extend: Tambah Infomasi \\
\hline 4 & Req-AD-2.2 & Extend:Hapus informasi \\
\hline 5 & Req-AD-3 & Kelola Product \\
\hline 6 & Req-AD-3.1 & Extend: Tambah Product \\
\hline 7 & Req-AD-3.2 & Extend: Lihat Daftar Product \\
\hline 9 & Req-AD-3.3 & Extend: Edit Product \\
\hline 10 & Req-AD-3.4 & Extend: Hapus Product \\
\hline 11 & Req-AD-4 & Kelola Buku Tamu \\
\hline 12 & Req-AD-4.1 & Extend: Jawab Buku tamu \\
\hline 13 & Req-AD-4.2 & Extend: Hapus Buku tamu \\
\hline 14 & Req-AD-5 & Kelola Member \\
\hline 15 & Req-AD-5.1 & Extend: Hapus Member \\
\hline 16 & Req-AD-6 & Kelola Pesanan \\
\hline 17 & Req-AD-6.1 & $\begin{array}{l}\text { Extend: } \\
\text { Pemesanan }\end{array}$ \\
\hline 18 & Req-AD-6.2 & Extend: Hapus pemesanan \\
\hline 19 & Req-AD-7 & Kelola Keranjang Belanja \\
\hline 20 & Req-AD-7.1 & $\begin{array}{l}\text { Extend: Hapus Keranjang } \\
\text { Belanja }\end{array}$ \\
\hline 21 & Req-AD-8 & Logout \\
\hline
\end{tabular}

\subsection{Permodelan Kebutuhan}

\subsubsection{Use case Diagram}

Diagram Use Case menggambarkan unit fungsionalitas yang disediakan oleh sistem. Tujuan utama diagram use-case adalah untuk membantu tim pengembangan memvisualisasikan persyaratan fungsional suatu sistem, termasuk hubungan "aktor" (manusia yang akan berinteraksi dengan sistem) ke proses penting, serta hubungan di antara penggunaan yang berbeda kasus. Berikut ini diagram use case yang dibuat:

1) Use Case Pengunjung Website

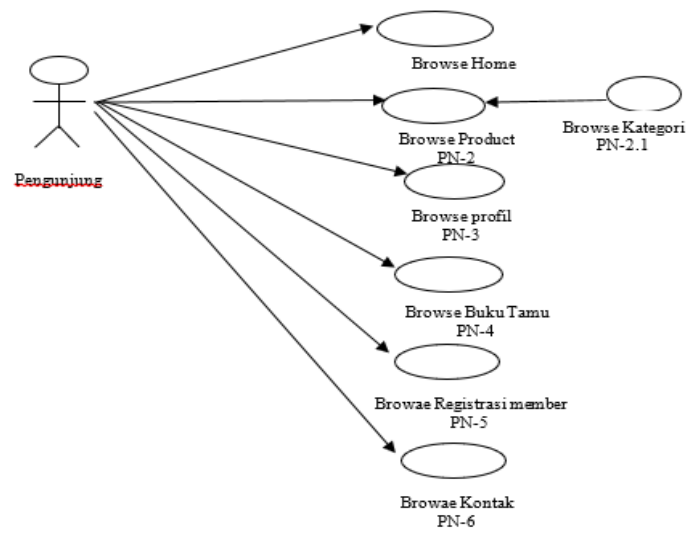

Gambar 2 Use Case Pengunjung
2) Use Case Diagram Member

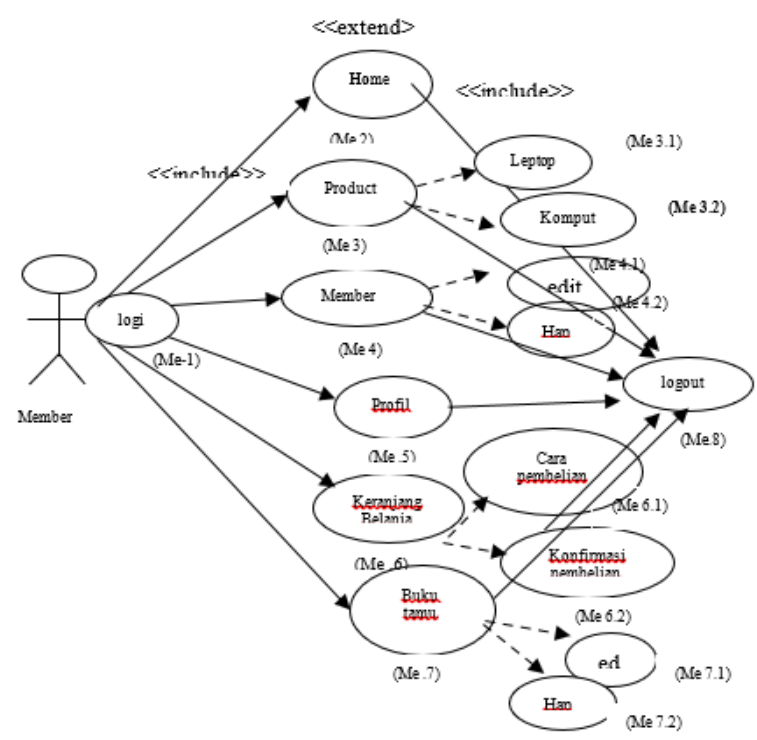

Gambar 3 Use Case Member

3) Use Case Diagram Admin

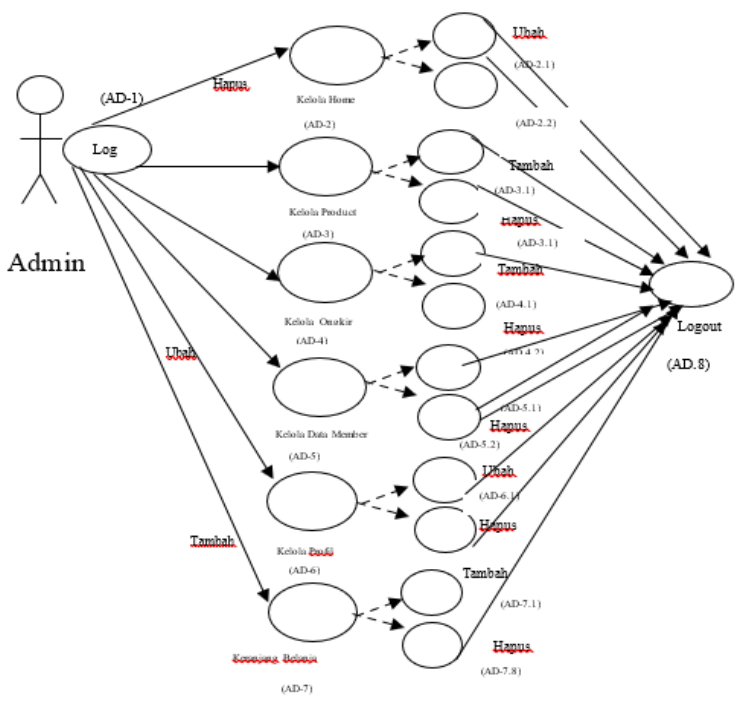

Gambar 4 Use Case Admin

\subsubsection{Flow of Event}

Flow of Event (alur peristiwa) adalah langkah-langkah yang diperlukan untuk melakukan dalam kasus penggunaan. Sekarang, dengan Paradigma Visual, Anda dapat menentukan struktur aliran kompleks dengan menentukan aliran kontrol, seperti if, while dan jump, di dalam langkah. Tutorial ini akan mendemonstrasikan bagaimana mendefinisikan aliran kendali dalam aliran kejadian. Berikut ini flow event yang dibuat:

1) Flow Event (Skenario) Pengunjung 
Tabel 5 Flow of Events Pengunjung1

\begin{tabular}{|l|l|}
\hline \multicolumn{2}{|l|}{ Identification } \\
\hline No Use case & PN-1 \\
\hline Nama Use Case & Browse Home(informasi) \\
\hline Deskripsi & $\begin{array}{l}\text { Proses untuk menampilkan } \\
\text { Home (informasi) }\end{array}$ \\
\hline Aktor & Pengunjung Website \\
\hline \multicolumn{2}{|c|}{ Skenario Utama } \\
\hline Kondisi Awal & - \\
\hline Aksi Aktor & \multicolumn{1}{|c|}{ Respon Sistem menampilkan } \\
\hline $\begin{array}{l}\text { Menjalankan } \\
\text { Website }\end{array}$ & $\begin{array}{l}\text { Sistem } \\
\text { Home(informasi) }\end{array}$ \\
\hline Kondisi Akhir & $\begin{array}{l}\text { Menu Home (informasi) } \\
\text { ditampilkan }\end{array}$ \\
\hline
\end{tabular}

Tabel 6 Flow of Events Pengunjung2

\begin{tabular}{|l|l|}
\hline \multicolumn{2}{|c|}{ Identification } \\
\hline No Use case & PN-2 \\
\hline $\begin{array}{l}\text { Nama Use } \\
\text { Case }\end{array}$ & Browse Product \\
\hline Deskripsi & Proses untuk menampilkan Product \\
\hline Aktor & Pengunjung Website \\
\hline \multicolumn{2}{|c|}{ Skenario Utama } \\
\hline $\begin{array}{l}\text { Kondisi } \\
\text { Awal }\end{array}$ & $\begin{array}{l}\text { Halaman Home website telah } \\
\text { ditampilkan }\end{array}$ \\
\hline \multicolumn{1}{|c|}{ Aksi Aktor } & \multicolumn{1}{|c|}{ Respon Sistem } \\
\hline $\begin{array}{l}\text { 1. Klik menu } \\
\text { Product }\end{array}$ & $\begin{array}{l}\text { 2. Sistem menload halaman Product } \\
\text { 3.Sistem menampilkan halaman } \\
\text { Product }\end{array}$ \\
\hline $\begin{array}{l}\text { Kondisi } \\
\text { Akhir }\end{array}$ & $\begin{array}{l}\text { Halaman Kategori } \\
\text { ditampilkan }\end{array}$ \\
\hline
\end{tabular}

Tabel 7 Flow of Events Pengunjung 2.1

\begin{tabular}{|l|l|}
\hline \multicolumn{2}{|c|}{ Identification } \\
\hline No Use case & PN-2.1 \\
\hline Nama Use Case & Browse Kategori Komputer \\
\hline Deskripsi & $\begin{array}{l}\text { Proses untuk menampilkan } \\
\text { Kategori Komputer }\end{array}$ \\
\hline \multicolumn{2}{|c|}{ Skenario Utama } \\
\hline Kondisi Awal & $\begin{array}{l}\text { Halaman Home website telah } \\
\text { ditampilkan }\end{array}$ \\
\hline Aksi Aktor & \multicolumn{1}{|c|}{ Respon Sistem } \\
\hline $\begin{array}{c}\text { 1.Klik menu } \\
\text { Kategori } \\
\text { komputer }\end{array}$ & $\begin{array}{l}\text { 2.Sistem meload menu } \\
\text { Kategori Komputer } \\
\text { 3.Sistem menampilkan menu } \\
\text { Kategori Komputer }\end{array}$ \\
\hline Kondisi Akhir & $\begin{array}{l}\text { Menu Kategori Komputer } \\
\text { ditampilkan }\end{array}$ \\
\hline
\end{tabular}

Tabel 8 Flow of Events Pengunjung 2.2

\begin{tabular}{|c|c|}
\hline \multicolumn{2}{|c|}{ Identification } \\
\hline No Use case & PN-2.2 \\
\hline Nama Use Case & Browse Kategori Leptop \\
\hline Deskripsi & $\begin{array}{l}\text { Proses untuk menampilkan } \\
\text { Kategori Leptop }\end{array}$ \\
\hline Aktor & Pengunjung Website \\
\hline \multicolumn{2}{|c|}{ Skenario Utama } \\
\hline Kondisi Awal & $\begin{array}{l}\text { Halaman Home website } \\
\text { telah ditampilkan }\end{array}$ \\
\hline Aksi Aktor & Respon Sistem \\
\hline $\begin{array}{l}\text { 1.Klik menu } \\
\text { Kategori } \\
\text { komputer }\end{array}$ & $\begin{array}{l}\text { 2.Sistem meload menu } \\
\text { Kategori Leptop } \\
\text { 3.Sistem menampilkan } \\
\text { menu Kategori Leptop }\end{array}$ \\
\hline Kondisi Akhir & $\begin{array}{l}\text { Menu Kategori Leptop } \\
\text { ditampilkan }\end{array}$ \\
\hline
\end{tabular}

Tabel 9 Flow of Events Pengunjung3

\begin{tabular}{|c|c|}
\hline \multicolumn{2}{|c|}{ Identification } \\
\hline No Use case & PN-3 \\
\hline Nama Use Case & Browse Profil \\
\hline Deskripsi & $\begin{array}{l}\text { Proses untuk menampilkan } \\
\text { Profil }\end{array}$ \\
\hline Aktor & Pengunjung Website \\
\hline \multicolumn{2}{|c|}{ Skenario Utama } \\
\hline Kondisi Awal & $\begin{array}{l}\text { Halaman Home website } \\
\text { telah ditampilkan }\end{array}$ \\
\hline Aksi Aktor & Respon Sistem \\
\hline $\begin{array}{l}\text { Klik menu } \\
\text { Web Link }\end{array}$ & $\begin{array}{l}\text { 1. Sistem meload } \\
\text { menu Profil }\end{array}$ \\
\hline & $\begin{array}{l}\text { 2. Sistem } \\
\text { menampilkan menu Profil }\end{array}$ \\
\hline Kondisi Akhir & Menu Profil Ditampilkan \\
\hline
\end{tabular}

Tabel 10 Flow of Events Pengunjung4

\begin{tabular}{|l|l|}
\hline \multicolumn{2}{|c|}{ Identification } \\
\hline No Use case & PN-4 \\
\hline Nama Use Case & Browse Buku Tamu \\
\hline Deskripsi & $\begin{array}{l}\text { Proses untuk menampilkan } \\
\text { Buku Tamu }\end{array}$ \\
\hline Aktor & Pengunjung Website \\
\hline \multicolumn{2}{|c|}{ Skenario Utama } \\
\hline Kondisi Awal & $\begin{array}{l}\text { Halaman Home website } \\
\text { telah ditampilkan }\end{array}$ \\
\hline \multicolumn{1}{|c|}{ Aksi Aktor } & \multicolumn{1}{c|}{ Respon Sistem } \\
\hline
\end{tabular}




\begin{tabular}{|c|c|}
\hline $\begin{array}{l}\text { Klik menu } \\
\text { Cara Regritasi } \\
\text { member }\end{array}$ & $\begin{array}{l}\text { 1. Sistem meload } \\
\text { menu Buku Tamu } \\
\text { 2. Sistem } \\
\text { menampilkan menu Buku }\end{array}$ \\
\hline Kondisi Akhir & $\begin{array}{l}\text { Tamu } \\
\text { Menu Buku } \\
\text { Ditampilkan }\end{array}$ \\
\hline
\end{tabular}

Tabel 11 Flow of Events Pengunjung5

\begin{tabular}{|l|l|}
\hline \multicolumn{2}{|c|}{ Identification } \\
\hline No Use case & PN-5 \\
\hline Nama Use Case & Input Registrasi Member \\
\hline Deskripsi & $\begin{array}{l}\text { Proses untuk melakukan } \\
\text { registrasi }\end{array}$ \\
\hline Aktor & Pengunjung Website \\
\hline \multicolumn{1}{|c|}{ Skenario Utama } \\
\hline Kondisi Awal & $\begin{array}{l}\text { Halaman Home website } \\
\text { telah ditampilkan }\end{array}$ \\
\hline \multicolumn{1}{|c|}{ Aksi Aktor } & \multicolumn{1}{|c|}{ Respon Sistem } \\
daftar menu & \multicolumn{1}{|c|}{$\begin{array}{l}\text { 1. Sistem meload } \\
\text { registrasi member baru }\end{array}$} \\
\hline $\begin{array}{l}\text { 2.menginput } \\
\text { registrasi member } \\
\text { baru }\end{array}$ & $\begin{array}{l}\text { 2. Sistem } \\
\text { menampilkan hasil input } \\
\text { registrasi member baru }\end{array}$ \\
\hline 3.klik menu daftar & $\begin{array}{l}\text { 3. Sistem akan } \\
\text { menampilkan daftar } \\
\text { member berhasil }\end{array}$ \\
\hline Kondisi Akhir & $\begin{array}{l}\text { Registrasi member akan di } \\
\text { proses }\end{array}$ \\
\hline
\end{tabular}

Tabel 12 Flow of Events Pengunjung6

\begin{tabular}{|l|l|}
\hline \multicolumn{2}{|c|}{ Identification } \\
\hline No Use case & PN-5 \\
\hline Nama Use Case & Input Kontak \\
\hline Deskripsi & $\begin{array}{l}\text { Proses untuk Hubungi } \\
\text { Kontak }\end{array}$ \\
\hline Aktor & Pengunjung Website \\
\hline \multicolumn{2}{|c|}{ Skenario Utama } \\
\hline Kondisi Awal & $\begin{array}{l}\text { Halaman Home website } \\
\text { telah ditampilkan }\end{array}$ \\
\hline \multicolumn{1}{|c|}{ Aksi Aktor } & \multicolumn{1}{|c|}{ Respon Sistem } \\
\hline \multicolumn{1}{|c|}{ Kontik menu } & $\begin{array}{l}\text { 2. Sistem meload Menu } \\
\text { Kontak }\end{array}$ \\
\hline Kondisi Akhir & $\begin{array}{l}\text { Menu Kontak akan di } \\
\text { proses }\end{array}$ \\
\hline
\end{tabular}

2) Flow Event (Skenario) Member

Tabel 13 Flow of Events Member 1

\section{Identification}

\begin{tabular}{|l|l|}
\hline $\begin{array}{l}\text { No. Use } \\
\text { Case }\end{array}$ & ME - 1 \\
\hline $\begin{array}{l}\text { Nama Use } \\
\text { Case }\end{array}$ & Login \\
\hline Deskripsi & $\begin{array}{l}\text { Proses untuk melakukan login } \\
\text { Member }\end{array}$ \\
\hline Aktor & Member \\
\hline \multicolumn{2}{|c|}{ Skenario Utama } \\
\hline $\begin{array}{l}\text { Kondisi } \\
\text { Awal }\end{array}$ & Member masuk halaman Home \\
\hline \multicolumn{1}{|c|}{ Aksi Aktor } & \multicolumn{1}{|c|}{ Respon Sistem } \\
\hline $\begin{array}{l}\text { Mengisi } \\
\text { username } \\
\text { dan password }\end{array}$ & $\begin{array}{l}\text { 1. Memvalidasi username } \\
\text { dan password } \\
\text { Member }\end{array}$ \\
\hline $\begin{array}{l}\text { Kondisi } \\
\text { Akhir }\end{array}$ & $\begin{array}{l}\text { Member berada dihalaman } \\
\text { member }\end{array}$ \\
\hline
\end{tabular}

Tabel 14 Flow of Events Member 2

\begin{tabular}{|l|l|}
\hline \multicolumn{2}{|c|}{ Identification } \\
\hline $\begin{array}{l}\text { No. Use } \\
\text { Case }\end{array}$ & ME-2 \\
\hline $\begin{array}{l}\text { Nama Use } \\
\text { Case }\end{array}$ & Browse Product \\
\hline Deskripsi & $\begin{array}{l}\text { Proses untuk menampilkan } \\
\text { halaman Product }\end{array}$ \\
\hline Aktor & Member \\
\hline \multicolumn{2}{|c|}{ Skenario Utama } \\
\hline $\begin{array}{l}\text { Kondisi } \\
\text { Awal }\end{array}$ & $\begin{array}{l}\text { Halaman Home (Informasi) } \\
\text { member ditampilkan }\end{array}$ \\
\hline Aksi Aktor & \multicolumn{1}{|c|}{ Respon Sistem } \\
\hline $\begin{array}{l}\text { Klik menu } \\
\text { Product }\end{array}$ & $\begin{array}{l}\text { 1. Sistem akan meload halaman } \\
\text { Product }\end{array}$ \\
\hline \multicolumn{2}{|c|}{ Sistem akan menampilkan } \\
halaman Product \\
\hline $\begin{array}{l}\text { Kondisi } \\
\text { Akhir }\end{array}$ & Halaman Product ditampilkan \\
\hline
\end{tabular}

Tabel 15 Flow of Events Member 3

\begin{tabular}{|c|c|}
\hline \multicolumn{2}{|r|}{ Identification } \\
\hline $\begin{array}{ll}\text { No. } & \text { Use } \\
\text { Case } & \end{array}$ & ME-4 \\
\hline $\begin{array}{l}\text { Nama Use } \\
\text { Case }\end{array}$ & Member \\
\hline Deskripsi & Proses untuk melihat data member \\
\hline Aktor & Member \\
\hline \multicolumn{2}{|r|}{ Skenario Utama } \\
\hline $\begin{array}{l}\text { Kondisi } \\
\text { Awal }\end{array}$ & Halaman home member ditampilkan \\
\hline Aksi Aktor & Respon Sistem \\
\hline
\end{tabular}




\begin{tabular}{|c|c|}
\hline $\begin{array}{l}\text { 1.Klik menu } \\
\text { Member }\end{array}$ & $\begin{array}{l}\text { 1. Sistem akan meload menu } \\
\text { Member }\end{array}$ \\
\hline & $\begin{array}{lll}\text { 2.Sistem } & \text { menampilkan } & \text { menu } \\
\text { Member } & & \end{array}$ \\
\hline $\begin{array}{l}\text { Kondisi } \\
\text { Akhir }\end{array}$ & $\begin{array}{l}\text { Halaman Menu Member Berhasil } \\
\text { ditampilkan }\end{array}$ \\
\hline
\end{tabular}

Tabel 16 Flow of Event Member 4

\begin{tabular}{|l|l|}
\hline \multicolumn{2}{|c|}{ Identification } \\
\hline No. Use Case & ME-4.1 \\
\hline Nama Use Case & Edit Data Member \\
\hline Deskripsi & $\begin{array}{l}\text { Proses untuk mengedit data } \\
\text { member }\end{array}$ \\
\hline Aktor & Member \\
\hline \multicolumn{2}{|c|}{ Skenario Utama } \\
\hline Kondisi Awal & $\begin{array}{l}\text { Halaman home member } \\
\text { ditampilkan }\end{array}$ \\
\hline \multicolumn{1}{|c|}{ Aksi Aktor } & \multicolumn{1}{|c|}{ Respon Sistem } \\
\hline $\begin{array}{l}\text { 1.Klik menu } \\
\text { Member }\end{array}$ & $\begin{array}{l}\text { 2.Sistem akan meload } \\
\text { menu Member }\end{array}$ \\
\cline { 2 - 2 } & $\begin{array}{l}\text { 3.Sistem menampilkan menu } \\
\text { Member }\end{array}$ \\
\hline $\begin{array}{l}\text { 4.Klik menu edit } \\
\text { Member }\end{array}$ & $\begin{array}{l}\text { Halaman Menu edit Member } \\
\text { Berhasil ditampilkan }\end{array}$ \\
\hline Kondisi Akhir
\end{tabular}

Tabel 17 Flow of Event Member 5

\begin{tabular}{|c|c|}
\hline \multicolumn{2}{|r|}{ Identification } \\
\hline No. Use Case & ME-4.2 \\
\hline $\begin{array}{ll}\text { Nama } & \text { Use } \\
\text { Case } & \\
\end{array}$ & Ubah Data Member \\
\hline Deskripsi & $\begin{array}{l}\text { Proses untuk menghapus data } \\
\text { member }\end{array}$ \\
\hline Aktor & Member \\
\hline \multicolumn{2}{|c|}{ Skenario Utama } \\
\hline Kondisi Awal & $\begin{array}{l}\text { Halaman home member } \\
\text { ditampilkan }\end{array}$ \\
\hline Aksi Aktor & Respon Sistem \\
\hline $\begin{array}{l}\text { 1.Klik menu } \\
\text { Member }\end{array}$ & $\begin{array}{l}\text { 2.Sistem akan meload menu } \\
\text { Member }\end{array}$ \\
\hline & $\begin{array}{l}\text { 3.Sistem menampilkan menu } \\
\text { Member }\end{array}$ \\
\hline $\begin{array}{l}\text { 4.Klik menu } \\
\text { Ubah Member }\end{array}$ & \\
\hline Kondisi Akhir & $\begin{array}{l}\text { Halaman Menu Ubah Member } \\
\text { Berhasil ditampilkan }\end{array}$ \\
\hline
\end{tabular}

Tabel 18 Flow of Events Member 6

\begin{tabular}{|l|l|}
\hline \multicolumn{2}{|c|}{ Identification } \\
\hline No. Use Case & ME-6 \\
\hline
\end{tabular}

\begin{tabular}{|c|c|c|}
\hline $\begin{array}{ll}\text { Nama } & \text { Use } \\
\text { Case } & \end{array}$ & \multicolumn{2}{|c|}{ Keranjang Belanja } \\
\hline Deskripsi & \multicolumn{2}{|c|}{$\begin{array}{l}\text { Proses untuk menampilkan } \\
\text { Keranjang Belanja }\end{array}$} \\
\hline Aktor & \multicolumn{2}{|c|}{ Member } \\
\hline \multicolumn{3}{|c|}{ Skenario Utama } \\
\hline Kondisi Awal & \multicolumn{2}{|c|}{$\begin{array}{l}\text { Halaman home member } \\
\text { ditampilkan }\end{array}$} \\
\hline \multicolumn{2}{|l|}{ Aksi Aktor } & Respon Sistem \\
\hline \multirow[t]{2}{*}{$\begin{array}{l}\text { 1.Klik } \quad \mathrm{M} \\
\text { Keranjang Belanj }\end{array}$} & $\begin{array}{l}\text { enu } \\
\text { ja }\end{array}$ & $\begin{array}{l}\text { 1. Sistem akan } \\
\text { meload Keranjang } \\
\text { Belanja }\end{array}$ \\
\hline & & $\begin{array}{l}\text { 2.Sistem menampilkan } \\
\text { Keranjang Belanja }\end{array}$ \\
\hline Kondisi Akhir & \multicolumn{2}{|c|}{$\begin{array}{lr}\text { Halaman } & \text { Keranjang } \\
\text { BelanjaBerhasil ditampilkan }\end{array}$} \\
\hline
\end{tabular}

Tabel 19 Flow of Events Member 7

\begin{tabular}{|l|l|}
\hline \multicolumn{2}{|c|}{ Identification } \\
\hline No. Use Case & ME -8 \\
\hline $\begin{array}{l}\text { Nama Use } \\
\text { Case }\end{array}$ & Logout \\
\hline Deskripsi & $\begin{array}{l}\text { Proses untuk melakukan logout } \\
\text { member }\end{array}$ \\
\hline Aktor & Member \\
\hline \multicolumn{2}{|c|}{ Skenario Utama } \\
\hline Kondisi Awal & $\begin{array}{l}\text { Member berada di halaman } \\
\text { member }\end{array}$ \\
\hline \multicolumn{1}{|c|}{ Aksi Aktor } & $\begin{array}{l}\text { Respon Sistem } \\
\text { 1.Klik tomban logout } \\
\text { logout }\end{array}$ \\
\hline Kondisi Akhir & $\begin{array}{l}\text { Member keluar dari halaman } \\
\text { utama Member }\end{array}$ \\
\hline
\end{tabular}

3) Flow Event (Skenario) Admin Tabel 20 Flow of Events Admin 1

\begin{tabular}{|c|c|c|}
\hline \multicolumn{3}{|c|}{ Identification } \\
\hline No. Use Case & \multicolumn{2}{|c|}{ AD - 1} \\
\hline Nama Use Case & \multicolumn{2}{|c|}{ Login } \\
\hline Deskripsi & \multicolumn{2}{|c|}{$\begin{array}{l}\text { Proses untuk melakukan login } \\
\text { Admin }\end{array}$} \\
\hline Aktor & \multicolumn{2}{|c|}{ Admin } \\
\hline \multicolumn{3}{|c|}{ Skenario Utama } \\
\hline Kondisi Awal & \multicolumn{2}{|c|}{ Admin berada dihalaman Login } \\
\hline Aksi Aktor & \multicolumn{2}{|c|}{ Respon Sistem } \\
\hline $\begin{array}{l}\text { 1. Mengisi En } \\
\text { dan Password }\end{array}$ & & $\begin{array}{l}\text { 1.Memvalidasi Email dan } \\
\text { password }\end{array}$ \\
\hline 2. Klik Login & & $\begin{array}{l}\text { 2.Menampilkan halaman } \\
\text { utama Login }\end{array}$ \\
\hline
\end{tabular}

Kondisi Akhir $\quad$ Admin berada dihalaman admin

Tabel 21 Flow of Events Admin 2 


\begin{tabular}{|c|c|}
\hline \multicolumn{2}{|r|}{ Identification } \\
\hline No. Use Case & AD-4 \\
\hline $\begin{array}{ll}\text { Nama } & \text { Use } \\
\text { Case }\end{array}$ & Kelola Menu Ongkir \\
\hline Deskripsi & $\begin{array}{ll}\text { Proses untuk melakukan } \\
\text { pengelolaan Ongkir yang ada } \\
\text { pada database }\end{array}$ \\
\hline Aktor & Admin \\
\hline \multicolumn{2}{|r|}{ Skenario Utama } \\
\hline Kondisi Awal & $\begin{array}{l}\text { Halaman } \\
\text { ditampilkan }\end{array}$ \\
\hline Aksi Aktor & Respon Sistem \\
\hline $\begin{array}{l}\text { 1.Klik menu kelola } \\
\text { Buku Tamu }\end{array}$ & $\begin{array}{l}\text { 1.Sistem akan meload data } \\
\text { Ongkir dari database }\end{array}$ \\
\hline & $\begin{array}{l}\text { 2. Sistem menampilkan data } \\
\text { Ongkir dari database }\end{array}$ \\
\hline Kondisi Akhir & $\begin{array}{l}\text { Halaman kelola Ongkir telah di } \\
\text { tampilkan }\end{array}$ \\
\hline
\end{tabular}

Tabel 22 Flow of Events Admin 2.2

\begin{tabular}{|l|l|}
\hline \multicolumn{2}{|c|}{ Identification } \\
\hline No. Use Case & AD-4.1 \\
\hline $\begin{array}{l}\text { Nama Use } \\
\text { Case }\end{array}$ & Hapus Menu Ongkir \\
\hline Deskripsi & $\begin{array}{l}\text { Proses untuk melakukan } \\
\text { hapus Menu Ongir yang ada } \\
\text { pada database }\end{array}$ \\
\hline Aktor & Admin \\
\hline \multicolumn{2}{|c|}{ Skenario Utama } \\
\hline Kondisi Awal & $\begin{array}{l}\text { Halaman kelola Ongkir telah } \\
\text { di tampilkan }\end{array}$ \\
\hline \multicolumn{1}{|c|}{ Aksi Aktor } & \multicolumn{1}{|c|}{ Respon Sistem } \\
\hline $\begin{array}{l}\text { 1.Klik tombol } \\
\text { hapus }\end{array}$ & $\begin{array}{l}\text { 1.Sistem akan memproses } \\
\text { data Ongkir }\end{array}$ \\
\hline & $\begin{array}{l}\text { 2.Sistem } \\
\text { menampilkan data telah } \\
\text { terhapus }\end{array}$ \\
\hline Kondisi Akhir & Data Ongkir telah di hapus \\
\hline
\end{tabular}

Tabel 23 Flow of Events Admin 3

\begin{tabular}{|l|l|}
\hline \multicolumn{2}{|c|}{ Identification } \\
\hline $\begin{array}{l}\text { No. Use } \\
\text { Case }\end{array}$ & AD-3 \\
\hline $\begin{array}{l}\text { Nama Use } \\
\text { Case }\end{array}$ & Kelola Data Product \\
\hline Deskripsi & $\begin{array}{l}\text { Proses untuk melakukan atau } \\
\text { mengecek daftar Product yang } \\
\text { ada pada database }\end{array}$ \\
\hline Aktor & Admin \\
\hline \multicolumn{2}{|c|}{ Skenario Utama } \\
\hline
\end{tabular}

\begin{tabular}{|l|l|}
\hline $\begin{array}{l}\text { Kondisi } \\
\text { Awal }\end{array}$ & $\begin{array}{l}\text { Halaman utama Admin } \\
\text { ditampilkan }\end{array}$ \\
\hline Aksi Aktor & \multicolumn{1}{|c|}{ Respon Sistem } \\
\hline $\begin{array}{l}\text { 1.Klik } \\
\text { menu } \\
\text { Product }\end{array}$ & $\begin{array}{l}\text { 1.Sistem akan meload } \\
\text { Product dari database }\end{array}$ \\
\hline & $\begin{array}{l}\text { 2.Sistem menampilkan data } \\
\text { Product dari database }\end{array}$ \\
\hline $\begin{array}{l}\text { Kondisi } \\
\text { Akhir }\end{array}$ & Menu Product di tampilkan \\
\hline
\end{tabular}

Tabel 24 Flow of Events Admin 3.1

\begin{tabular}{|l|l|}
\hline \multicolumn{2}{|c|}{ Identification } \\
\hline No. Use Case & AD-3.1 \\
\hline Nama Use Case & kelola Tambah Product \\
\hline Deskripsi & $\begin{array}{l}\text { Proses untuk melakukan } \\
\text { tambah Product }\end{array}$ \\
\hline Aktor Skenario Utama \\
\hline \multicolumn{2}{|c|}{ Sdmin } \\
\hline Kondisi Awal & $\begin{array}{l}\text { Menu Kelola Product telah } \\
\text { ditampilkan }\end{array}$ \\
\hline \multicolumn{1}{|c|}{ Aksi Aktor } & \multicolumn{1}{|c|}{ Respon Sistem } \\
\hline $\begin{array}{l}\text { 1. Klik menu } \\
\text { tambah catalog }\end{array}$ & $\begin{array}{l}\text { 1.Sistem menampilkan data Product } \\
\text { memproses }\end{array}$ \\
\hline $\begin{array}{l}\text { 2.Mengisi data } \\
\text { katalog baru }\end{array}$ & $\begin{array}{l}\text { 2.Sistem penambahan data Product } \\
\text { baru } \\
\text { baru pesan }\end{array}$ \\
\hline 3.Klik simpan & $\begin{array}{l}\text { 3.Menampilkan } \\
\text { database tersimpan }\end{array}$ \\
\hline Kondisi Akhir & Data Product telah tersimpan \\
\hline
\end{tabular}

Tabel 25 Flow of Events Admin 3.2

\begin{tabular}{|l|l|}
\hline \multicolumn{2}{|c|}{ Identification } \\
\hline No. Use Case & AD-3.2 \\
\hline $\begin{array}{l}\text { Nama Use } \\
\text { Case }\end{array}$ & Hapus Product \\
\hline Deskripsi & $\begin{array}{l}\text { Proses untuk Menghapus } \\
\text { Product }\end{array}$ \\
\hline Aktor & Admin \\
\hline \multicolumn{2}{|c|}{ Skenario Utama } \\
\hline $\begin{array}{l}\text { Kondisi } \\
\text { Awal }\end{array}$ & Halaman lihat daftar Product \\
\hline \multicolumn{1}{|c|}{ Aksi Aktor } & \multicolumn{1}{|c|}{ Respon Sistem } \\
\hline $\begin{array}{l}\text { 1. Klik tombol } \\
\text { Hapus }\end{array}$ & $\begin{array}{l}\text { 2. Sistem akan Menghapus } \\
\text { data Product }\end{array}$ \\
\hline $\begin{array}{l}\text { Kondisi } \\
\text { Akhir }\end{array}$ & Data product telah Di hapus \\
\hline
\end{tabular}

Tabel 26 Flow of Events Admin 4 Identification 


\begin{tabular}{|l|l|}
\hline $\begin{array}{l}\text { No. Use } \\
\text { Case }\end{array}$ & AD-4 \\
\hline $\begin{array}{l}\text { Nama Use } \\
\text { Case }\end{array}$ & Kelola Data member \\
\hline Deskripsi & $\begin{array}{l}\text { Proses untuk melakukan } \\
\text { kelolaData member yang ada pada } \\
\text { database }\end{array}$ \\
\hline Aktor & Admin \\
\hline \multicolumn{3}{|c|}{ Skenario Utama } \\
\hline $\begin{array}{l}\text { Kondisi } \\
\text { Awal }\end{array}$ & $\begin{array}{l}\text { Halaman utama admin di } \\
\text { tampilkan }\end{array}$ \\
\hline \multicolumn{1}{|c|}{ Aksi Aktor } & \multicolumn{2}{|c|}{ Respon Sistem } \\
\hline $\begin{array}{l}\text { Klik tombol } \\
\text { Kelola Member }\end{array}$ & $\begin{array}{l}\text { 1.Sistem akan meload } \\
\text { member dari database }\end{array}$ \\
\hline \multicolumn{3}{|l|}{$\begin{array}{l}\text { 2.sistem menampilkan data } \\
\text { member dari database }\end{array}$} \\
\hline $\begin{array}{l}\text { Kondisi } \\
\text { Akhir }\end{array}$ & Data member akan tampil \\
\hline
\end{tabular}

Tabel 27 Flow of Events Admin 4.1

\begin{tabular}{|l|l|}
\hline \multicolumn{2}{|c|}{ Identification } \\
\hline No. Use Case & AD-4.1 \\
\hline Nama Use Case & Hapus Data Member \\
\hline Deskripsi & $\begin{array}{l}\text { Proses untuk melakukan Hapus } \\
\text { Data Member }\end{array}$ \\
\hline Aktor & Admin \\
\hline \multicolumn{2}{|c|}{ Skenario Utama } \\
\hline Kondisi Awal & $\begin{array}{l}\text { Data Member telah } \\
\text { ditampilkan }\end{array}$ \\
\hline \multicolumn{1}{|c|}{ Aksi Aktor } & \multicolumn{1}{|c|}{ Respon Sistem } \\
\hline $\begin{array}{l}\text { Klik tombol } \\
\text { Hapus }\end{array}$ & $\begin{array}{l}\text { Sistem akan menampilkan } \\
\text { pesan member telah di hapus }\end{array}$ \\
\hline Kondisi Akhir & Data Member telah di kelola \\
\hline
\end{tabular}

Tabel 28 Flow of Events Admin 5

\begin{tabular}{|l|l|}
\hline \multicolumn{2}{|c|}{ Identification } \\
\hline No. Use Case & AD-5 \\
\hline $\begin{array}{l}\text { Nama Use } \\
\text { Case }\end{array}$ & Kelola informasi \\
\hline Deskripsi & $\begin{array}{l}\text { Proses untuk melakukan } \\
\text { pengelolaan Infomasi yang ada } \\
\text { pada database }\end{array}$ \\
\hline Aktor & Admin \\
\hline \multicolumn{2}{|c|}{ Skenario Utama } \\
\hline Kondisi Awal & $\begin{array}{l}\text { Halaman utama admin } \\
\text { ditampilkan }\end{array}$ \\
\hline \multicolumn{1}{|c|}{ Aksi Aktor } & \multicolumn{1}{|c|}{ Respon Sistem } \\
\hline $\begin{array}{l}\text { Klik menu } \\
\text { Kelola } \\
\text { Informasi }\end{array}$ & $\begin{array}{l}\text { Informasi dari database } \\
\text { Informelad data }\end{array}$ \\
\hline
\end{tabular}

\begin{tabular}{|l|lr|}
\hline & $\begin{array}{l}\text { 2. Sistem menampilkan data } \\
\text { Informasi dari database }\end{array}$ \\
\hline Kondisi Akhir & $\begin{array}{l}\text { Halaman kelola akan di } \\
\text { tampilkan }\end{array}$ \\
\hline
\end{tabular}

Tabel 29 Flow of Events Admin 5.1

\begin{tabular}{|l|l|}
\hline \multicolumn{2}{|c|}{ Identification } \\
\hline No. Use Case & AD-5.1 \\
\hline $\begin{array}{l}\text { Nama Use } \\
\text { Case }\end{array}$ & Ubah Informasi \\
\hline Deskripsi & $\begin{array}{l}\text { Proses untuk melakukan } \\
\text { Tambah Informasi }\end{array}$ \\
\hline Aktor & Admin \\
\hline \multicolumn{1}{|c|}{ Skenario Utama } \\
\hline Kondisi Awal & $\begin{array}{l}\text { Halaman kelola informasi telah } \\
\text { ditampilkan }\end{array}$ \\
\hline \multicolumn{1}{|c|}{ Aksi Aktor } & \multicolumn{1}{|c|}{ Respon Sistem } \\
\hline $\begin{array}{l}\text { 1. Klik tombol } \\
\text { Ubah }\end{array}$ & $\begin{array}{l}\text { 1.Sistem akan menampilkan } \\
\text { data Informasi } \\
\text { data baru akan memproses } \\
\text { informasi baru }\end{array}$ \\
\hline 3.Klik submit & \multicolumn{2}{|c|}{} \\
\hline Kondisi Akhir & Data Informasi telah di kelola \\
\hline
\end{tabular}

Tabel 30 Flow of Events Admin 5.2

\begin{tabular}{|l|l|}
\hline \multicolumn{2}{|c|}{ Identification } \\
\hline No. Use Case & AD-5.2 \\
\hline $\begin{array}{l}\text { Nama Use } \\
\text { Case }\end{array}$ & Hapus Informasi \\
\hline Deskripsi & $\begin{array}{l}\text { Proses untuk melakukan Hapus } \\
\text { Informasi }\end{array}$ \\
\hline Aktor & Admin \\
\hline \multicolumn{2}{|c|}{ Skenario Utama } \\
\hline Kondisi Awal & $\begin{array}{l}\text { Halamn kelola informasi telah } \\
\text { ditampilkan }\end{array}$ \\
\hline \multicolumn{1}{|c|}{ Aksi Aktor } & \multicolumn{1}{|c|}{ Respon Sistem } \\
\hline $\begin{array}{l}\text { Klik tombol } \\
\text { Hapus }\end{array}$ & $\begin{array}{l}\text { 1.Sistem akan memproses } \\
\text { data Informasi }\end{array}$ \\
\hline & $\begin{array}{l}\text { 2.Sistem akan menampilkan } \\
\text { data telah terhapus }\end{array}$ \\
\hline $\begin{array}{l}\text { Kondisi } \\
\text { Akhir }\end{array}$ & Data Informasi telah Di Hapus \\
\hline
\end{tabular}

Tabel 31 Flow of Events Admin 6

\begin{tabular}{|l|l|}
\hline \multicolumn{2}{|c|}{ Identification } \\
\hline No. Use Case & AD $-\mathbf{8}$ \\
\hline $\begin{array}{l}\text { Nama Use } \\
\text { Case }\end{array}$ & Logout \\
\hline Deskripsi & $\begin{array}{l}\text { Proses untuk melakukan } \\
\text { logout admin }\end{array}$ \\
\hline Aktor & Admin \\
\hline
\end{tabular}




\begin{tabular}{|c|l|l|}
\hline \multicolumn{2}{|c|}{ Skenario Utama } \\
\hline Kondisi Awal & $\begin{array}{l}\text { Admin berada di halaman } \\
\text { admin }\end{array}$ \\
\hline Aksi Aktor & \multicolumn{2}{|c|}{ Respon Sistem } \\
\hline 1. Klik tombol logout & $\begin{array}{l}\text { 2. Sistem } \\
\text { menampilkan } \\
\text { logout }\end{array}$ \\
\hline Kondisi Akhir & Keluar dari halaman admin \\
\hline
\end{tabular}

\subsubsection{Activity Diagram}

Activity diagrams (diagram aktivitas) menunjukkan aliran kontrol prosedural antara dua atau lebih banyak objek kelas saat memproses suatu aktivitas. Diagram aktivitas bisa digunakan untuk memodelkan proses bisnis tingkat yang lebih tinggi di tingkat unit bisnis, atau untuk memodelkan tindakan kelas internal tingkat rendah.

1. Business activity diagram Home

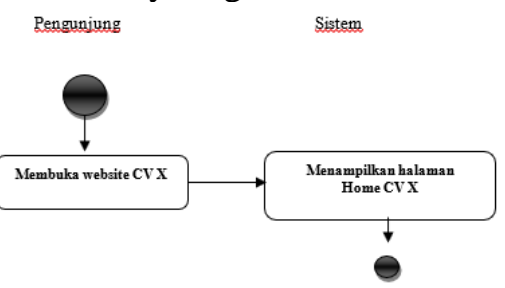

Gambar 5 Business Activity Diagram Home

2. Business activity diagram Profil

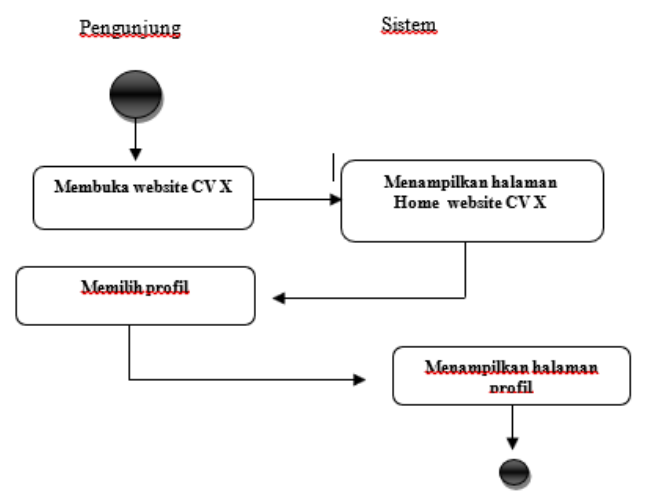

Gambar 6 Business Activity Diagram Profil

3. Business activity diagram Product

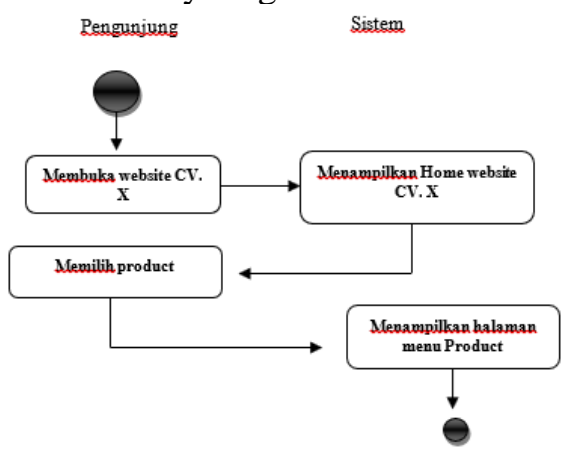

Gambar 7 Business Activity Diagram Product

4. Business activity diagram Buku Tamu

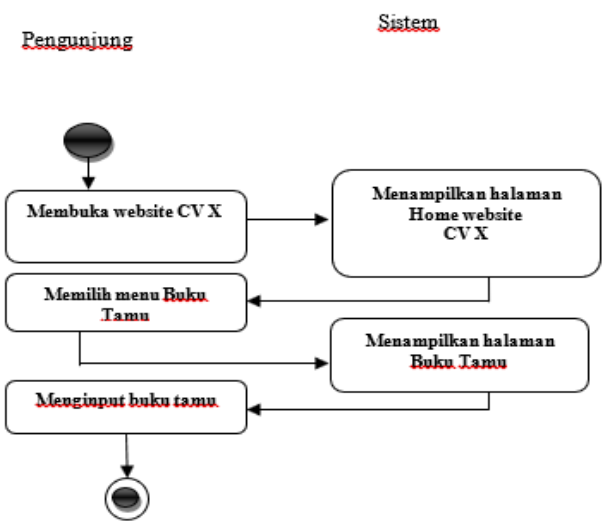

Gambar 8 Business Activity Diagram Buku Tamu

5. Business activity diagram Regristasi

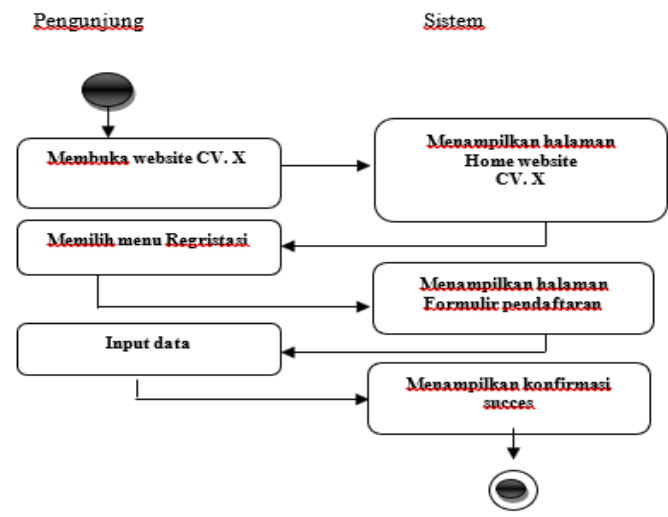

Gambar 9 Business Activity Diagram Regristrasi Member

6. Business activity diagram Login Member

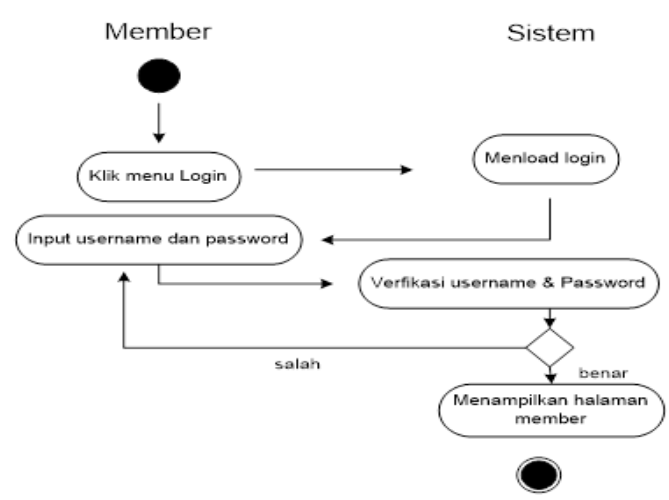

Gambar 10 Business Activity Diagram Login Member

7. Business activity diagram Kerabjang Belanja 


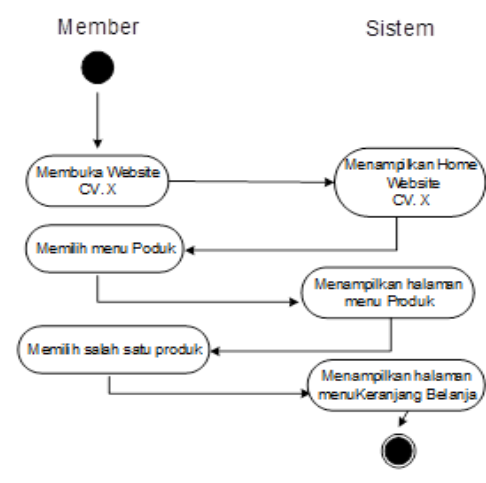

Gambar 11 Business Activity Diagram Keranjang Belanja

8. Business activity diagram Logout Member

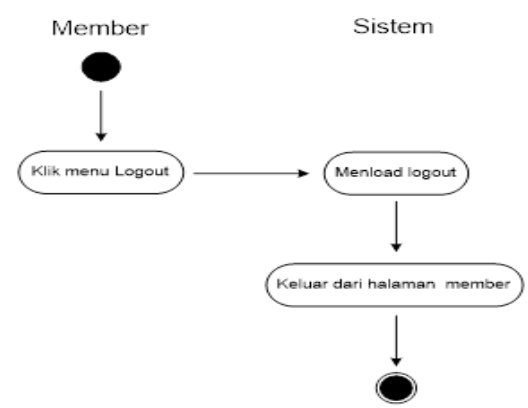

Gambar 12 Business Activity Diagram Logout

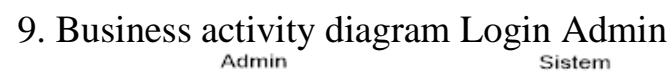

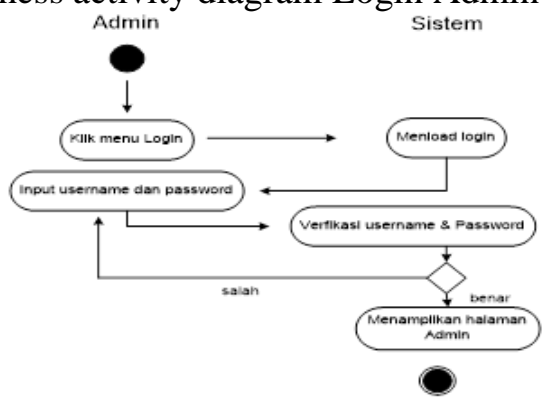

Gambar 13 Business Activity Diagram Login

10. Business activity diagram kelola Member

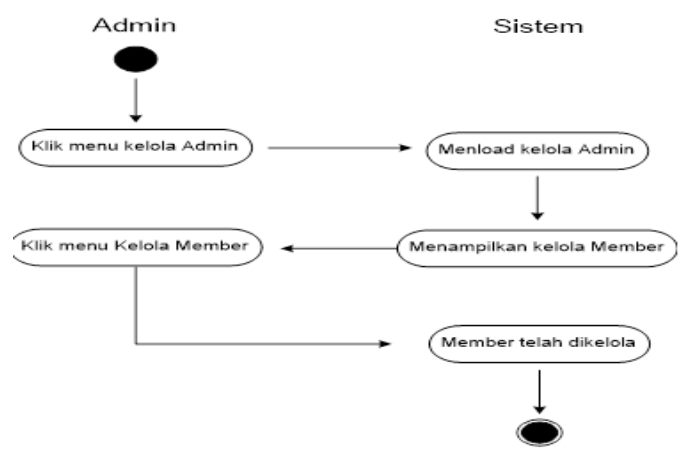

Gambar 14 Business Activity Diagram Kelola Admin

11. Business activity diagram kelola Product

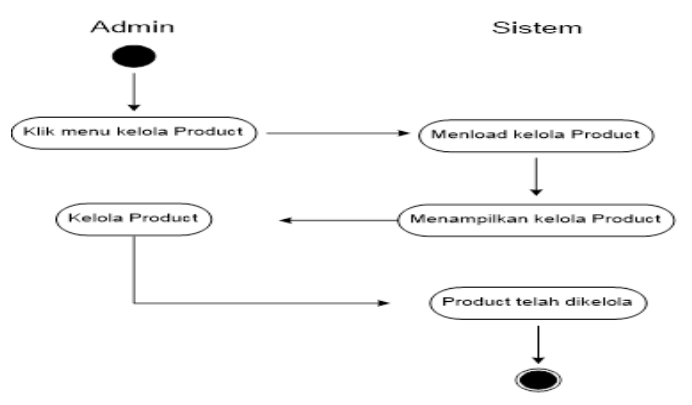

Gambar 15 Business Activity Diagram Kelola Product

12. Business activity diagram kelola Profil

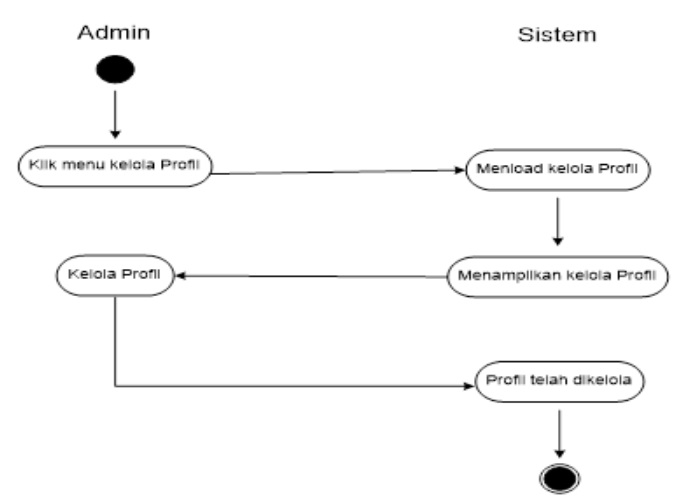

Gambar 16 Business Activity Diagram Kelola Profil

13. Business activity diagram kelola Ongkir 


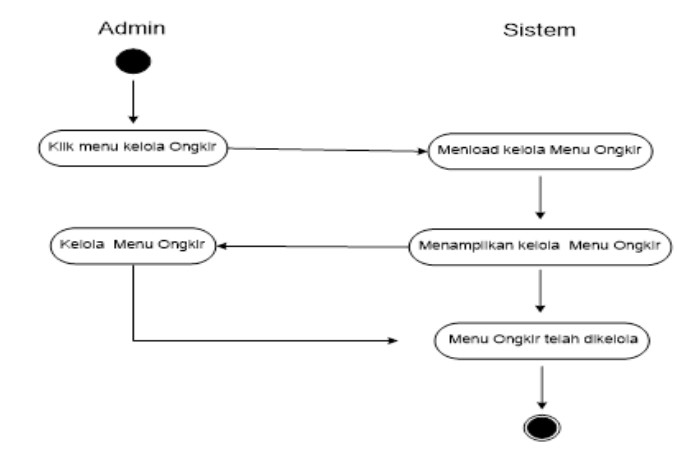

Gambar 17 Business Activity Diagram Kelola Ongkir

14. Business activity diagram kelola logout admin

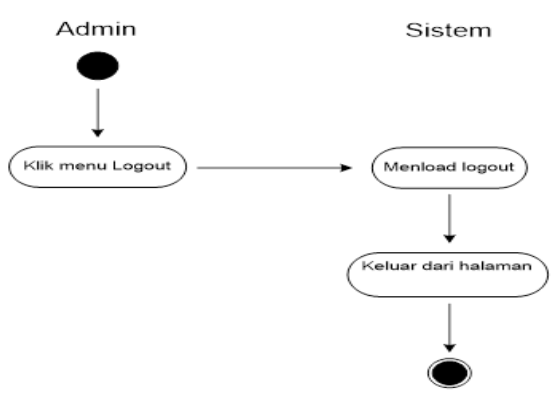

Gambar 18 Business Activity Diagram Kelola logout admin

\section{Hasil dan Pembahasan}

\subsection{Perancangan Perangkat Lunak}

Perancangan perangkat lunak merupakan gambaran secara garis besar sistem yang dibuat pada penelitian ini yang digambarkan dengan sequence diagram dan sketsa antarmuka sebagai berikut:

\subsection{Sequence Diagram}

Sequence diagram (diagram urutan) menunjukkan aliran mendetail untuk kasus penggunaan tertentu atau bahkan hanya bagian dari kasus penggunaan tertentu. Mereka hampir cukup jelas; mereka menunjukkan panggilan antara objek yang berbeda dalam urutan dan kalengnya menunjukkan, pada tingkat yang mendetail, panggilan yang berbeda ke objek yang berbeda.

Diagram urutan memiliki dua dimensi: Dimensi vertikal menunjukkan urutan pesan / panggilan dalam urutan waktu terjadinya; Dimensi horizontal menunjukkan contoh objek yang di pesan terkirim. Berikut ini Sequence Ddiagram yang dibuat:

\section{Browse Product}

Pada gambar 19 menggambarkan pengunjung menampilkan atau melihat daftar produk.

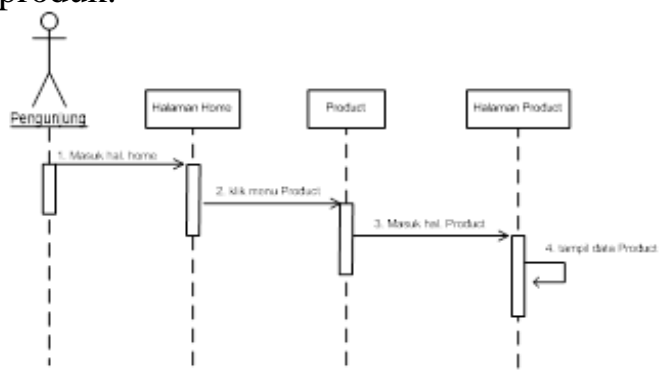

Gambar 19 Sequence Diagram Product

\section{Browse Profil}

Pada gambar 20 menggambarkan pengunjung menampilkan atau melihat profil.

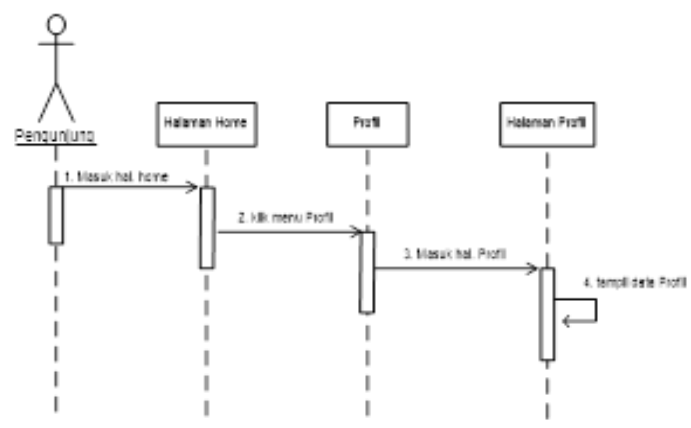

Gambar 20 Sequence Diagram Profil

\section{Browse Buku Tamu}

Pada gambar 21 menggambarkan pengunjung mengisi buku tamu.

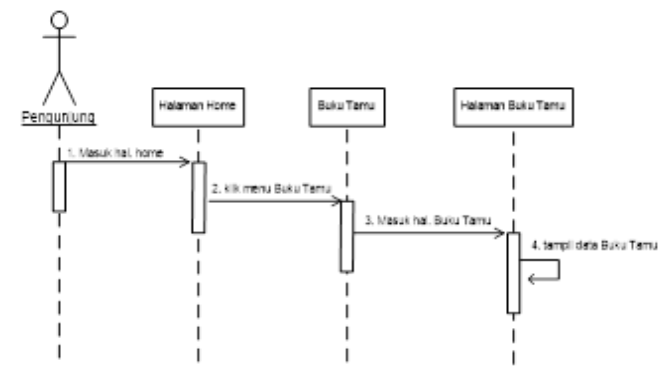

Gambar 21 Sequence Diagram Buku tamu

\subsection{Class Diagram}

Diagram kelas menunjukkan bagaimana entitas yang berbeda (orang, benda, dan data) berhubungan satu sama lain; dengan kata lain, ini menunjukkan struktur statis sistem, maka dapat dibuat Diagram kelas penjualan komputer berbasis Website di CV. X, di mana pada gambar 22 menunjukkan diagram kelas pengunjung, yang 
mana entitas pengunjung berelasi dengan entitas lainnya (buku tamu, reg member, profil, member, produk, keranjang belanja, cara pemesanan, dan konfirmasi pembayaran). Sedangkan pada gambar 23 menunjukkan diagram kelas admin, yang mana entitas admin berelasi dengan entitas lainnya (buku tamu, reg member, profil, produk, keranjang belanja, cara pemesanan, dan konfirmasi pembayaran).

\subsubsection{Class Diagram Pengunjung}

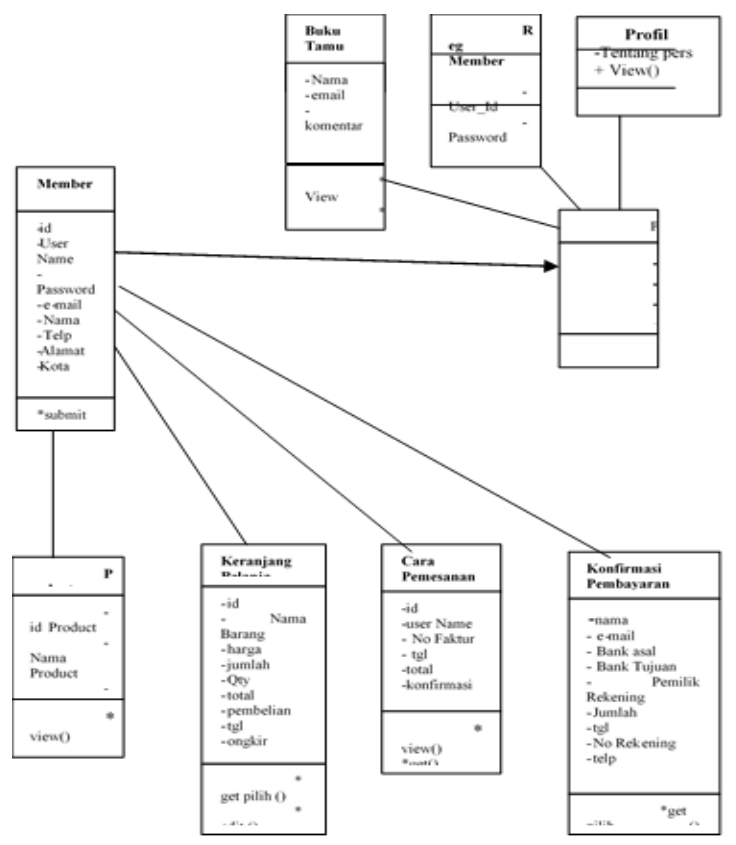

Gambar 22 Class Diagram Pengunjung

\subsubsection{Class Diagram Admin}

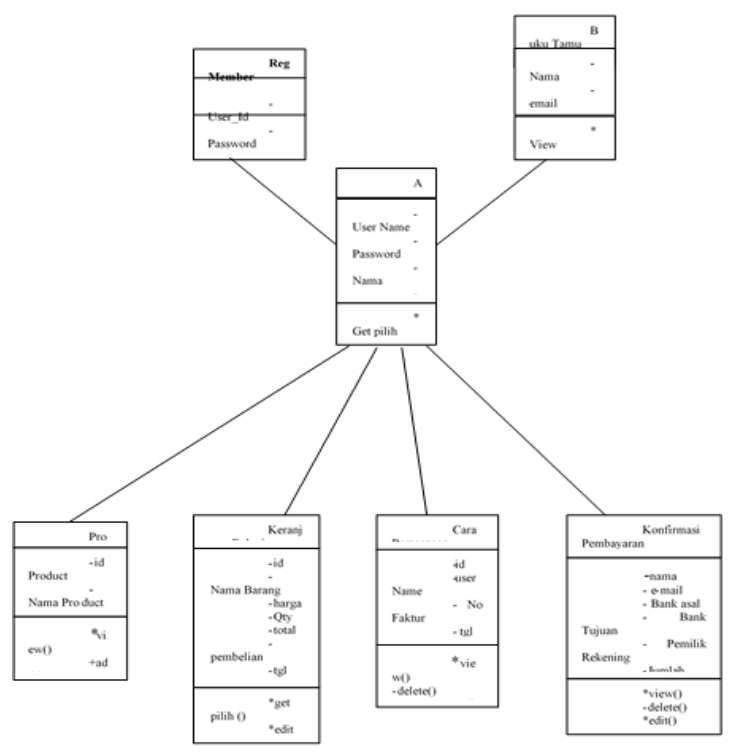

Gambar 23 Class Diagram Admin

\subsection{Antarmuka Pemakai}

Berikut ini adalah gambar perancangan user interface atau antarmuka pemakai antara pengunjung website, member, dan admin.

\subsubsection{Halaman Home}

Tampilan layar utama berfungsi sebagai seperti menu bagi pengujung sebelum melanjutkan melakukan aktifitas belanja atau sekedar melihatlihat saja.

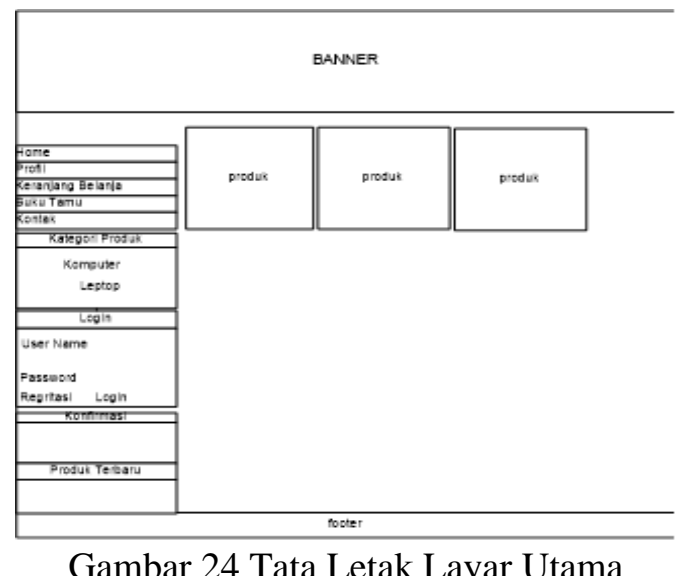

\subsubsection{Halaman Buku Tamu}

Tampilan halaman buku tamu diperuntukkan bagi pengunjung yang ingin melakukan pendaftaran pada sistem.

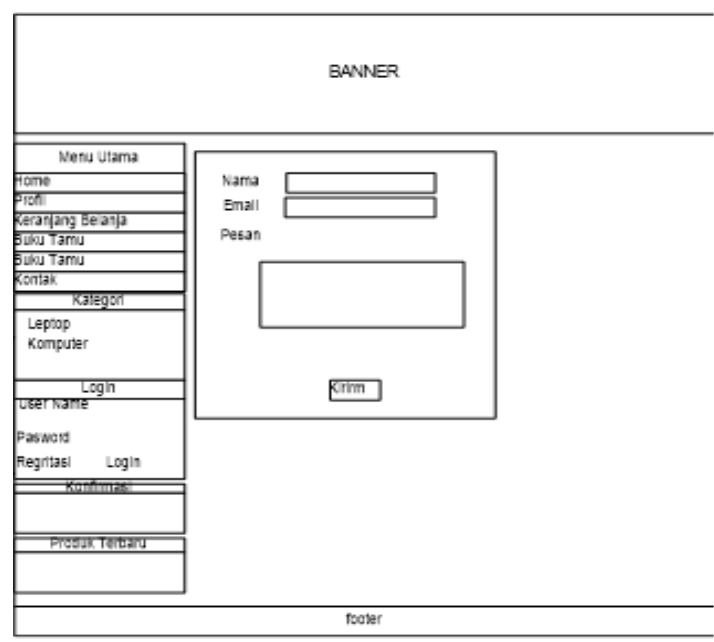

Gambar 25 Tata Letak Buku Tamu

\subsubsection{Halaman Login Admin}

Tampilan login diperuntukan sebagai pembatasan hak akses. 


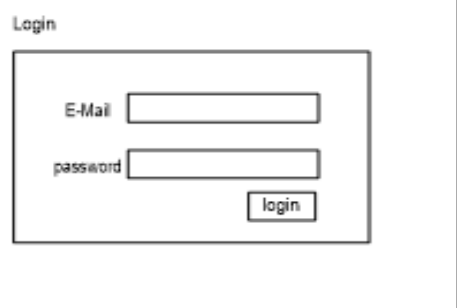

Gambar 26 Tata Letak Halaman Login

\section{Simpulan}

Dari hasil pengembangan website CV. X, maka penulis dapat menarik kesimpulan sebagai berikut: Perancangan website ini dapat meningkatkan waktu pelayanan dengan cara online tanpa batas, Perancangan website ini dapat menjadi media promosi yang dapat menjangkau pasar lebih luas dan lebih baik, dan Perancangan website ini dapat menjadi sarana komunikasi alternatif.

\section{Referensi}

Alter, S. (2008). Defining information systems as work systems: implications for the IS field. European Journal of Information Systems, 17(5), 448-469.

Bell, D. (2003). UML basics: An introduction to the Unified Modeling Language. The Rational Edge.

Fathansyah. (1999). Basis Data. Bandung: Informatika Bandung.

Hanum, W. S., \& Saifudin, A. (2019). Rancang Bangun Aplikasi Panduan Pariwisata di Kabupaten Banyuwangi Mobile Berbasis Android. Jurnal Teknologi Sistem Informasi Dan Aplikasi, 2(2), 59-65.

Kristanto, H. (1994). Konsep dan Perancangan Database. Yogyakarta: Andi.

Muslihudin, M. \& Oktavianto. (2016). Analisis dan Perancangan Sistem Informasi Menggunakan Model Terstruktur dan UML. Yogyakarta: Andi.

Nugroho, A. (2005). Rational Rose untuk Pemodelan Berorientasi Objek. Bandung: Informatika Bandung.

Singh, S. (2015). Database management system. Journal of Management Research and Analysis, 2(1), $72-$ 80.

Taufiq, R. (2018). Pengantar Sistem Informasi. Jakarta: Mitra Wacana Media.

Taufiq, R., Magfiroh, D. A., Yusuf, D., \& Yulianti, Y. (2020). Analisis dan Desain Sistem Informasi Pembayaran Sumbangan Pembinaan Pendidikan (SPP) di SMK Avicena Rajeg. Jurnal Teknologi Sistem Informasi dan Aplikasi, 3(1), 15-21.

Wilkinson, J. W. (1992). Accounting and Information Systems. New York: John Wiley \& Sons, Inc. 